\title{
Characterisation of Agri-Landscape Systems at a Regional Level: A Case Study in Northern Tuscany
}

\author{
Mariassunta Galli*, Enrico Bonari, Elisa Marraccini, Marta Debolini \\ Land Lab, Scuola Superiore Sant'Anna \\ Piazza Martiri della Libertà 33, 56127 Pisa, Italy
}

Received: 14 September 2009. Accepted: 29 March 2010.

\begin{abstract}
Preserving our landscape in sustainable development processes is now widely considered as fundamental. It is a complex and evolving issue that can be tackled from several perspectives. Agronomy can contribute to analyzing the relationships between agricultural production systems (cropping, farming and agricultural systems) at different levels (field, farm, and region) and the agricultural landscape (in terms of patches, matrixes, dynamics, etc). This is of particular interest where the relationships between "what and how" are produced by agricultural activities and the landscape are changing. In this case their own reciprocity may represent an opportunity to analyze complex systems, such as the characterization of agri-landscapes at a regional level.

We propose a case study developed as an up-scaling analytical process from a farm to a regional level. The result was the identification of six main agri-landscape systems highlighting the landscape drivers that are changing the traditional landscape of a rural region in Northern Tuscany (Lunigiana).
\end{abstract}

Key-words: agricultural systems, landscape, farm land use, sustainability.

\section{Introduction}

Sustainability research has significantly contributed to a renewal of agronomy studies that are much more oriented towards an integration of different types of knowledge at different spatial levels (Lichtfouse et al., 2009). There is an increasing interest in landscape studies where agronomy contributes through the analysis of the relationships between agricultural management at different levels, for example fields, farms, and regions, and their effects on the landscape (Deffontaines et al., 1995; Veburg et al., 2006; Bonari et al., 2006; Carpani et al., 2008; Giupponi et al., 2008). This is particularly the case both where the agricultural systems are changing and where they are more vulnerable to change. For this reason, there is an increasing interest in improving multi-scale approaches in agronomy and also in developing innova- tive methods on a regional scale in landscape studies (Veldkamp et al., 2001; Borin and Ceccon, 2002; Giupponi and Carpani, 2006; Ragaglini et al., 2008).

The relationships between the landscape and cropping, farming and agricultural systems can be analyzed in two different ways. In the first approach, levels are considered as spatial contexts where these systems and relationships take place. Therefore a field is the appropriate spatial context to analyse cropping systems, farmland for farming systems, and a part of a region or a whole region (e.g. a group of fields, a municipality, an eco-zone, an administrative region) for agricultural systems (Borin and Ceccon, 2002; Viglizzo et al., 2004). Each level corresponds to a different landscape characterization.

In the second approach, levels are considered as different spatial contexts where the systems express their landscape functions (Mar- 
raccini et al., 2008; Thenail et al., 2009), but each level is related to the others in the characterization of its own landscape. Therefore, in an upscaling perspective, the main interactions of the different landscape functions of the farming and cropping systems may be integrated by landscape functions of the agricultural system. On the contrary, in a downscaling perspective, the definition of the landscape function of an agricultural system enable to select and analyze how landscape functions of different farming and cropping systems contribute to that one at regional scale.

In this second approach, the analysis of each level and of their relationships can be approached as a process (Dorè et al., 2008; Galli et al., 2008). In other words the research is composed of several steps where the same case study is analyzed from different spatial (and temporal) levels and by making use both of quantitative and qualitative research methods to interpret the complexity in a more comprehensive way (Giupponi and Carpani, 2006; Roggero et al., 2006; Van Ittersum et al., 2007). The qualitative methods, which are mainly participatory, are essential for two reasons. Firstly, when the social context is relevant and can be acquired only by direct surveys (Antrop and Rogge, 2006). Secondly, when the quantitative characterization of the agricultural systems is limited by local dynamics, for example part-time farming, hobby farming (Primdhal, 1999; Paquette and Domon, 2003;), which may then result in a lack of proper data.

Many geographical studies on agriculture have showed that these methods can also be efficient at representing agricultural dynamics at different spatial levels (Capitaine and Benoit, 2001; Lardon and Piveauteau, 2002). Local knowledge can also help to solve complex issues, such as landscape problems (Roggero and Silvestri, 2002; Roggero et al., 2006; Van Ittersum et al., 2007, Giupponi et al., 2008). From a landscape planning and management perspective, participatory approaches are also supported by the European Landscape Convention. The Convention encourages local and regional authorities, along with other local decision-makers, to initiate participatory processes to improve their knowledge on landscapes. This entails the participation of local stakeholders to identify different landscapes, their characteristics and dynamics.
If the farmland can be considered the place where different agricultural production systems (cropping, farming and agricultural system) and their relationships with landscape may be basically analysed (Deffontaines et al., 1995; van Mansvelt, 1997; Thenail and Baudry, 2004; Bonari et al., 2006) in order to implement specific landscape management measures, the farmland level is rarely generalized to larger levels.

The aim of our study was therefore to characterise agri-landscape systems and their dynamics, by up-scaling landscape analyses from the farm to regional levels. We used agri-landscape systems to identify sub-regions where the reciprocal relationships between land uses, farming and landscape features were clear. We applied this agri-landscape characterisation to a case study in Northern Tuscany.

\section{Study area}

The study area is Lunigiana $\left(975 \mathrm{Km}^{2}\right)$, a geographical system located in Northern Tuscany, Italy (Fig. 1).

The study area is mainly characterized by uplands and mountains covering 15 municipalities and is designated as a "mountain community". On the whole, the area is recognized as a disadvantaged district (Council Directive 75/268 and subsequent legislation). According to the Strategic National Italian Plan for Rural Development, only the municipality of Aulla is classed as an "intermediate rural areas in transition". Fosdinovo, Podenzana and Tresana municipalities are classed as "intermediate rural areas in decline", whereas Bagnone, Casola in Lunigiana, Comano, Filattiera, Fivizzano, Licciana Nardi, Mulazzo, Pontremoli, Villafranca in Lunigiana and Zeri Municipalities are classed as "rural areas with overall development problems".

The total agricultural area is 43,717 ha corresponding to $45 \%$ of the total studied area. According to the 2000 Agricultural Census (ISTAT, 2000), $77 \%$ of the total of 7,700 farms has an area of less than 5 ha. The average total farm area is around 6 ha, but only one third is usable agricultural area (UAA). Moreover, $98 \%$ of the farms is family run. This percentage is higher than the regional average of all mountain communities in Tuscany. However, compared to the 


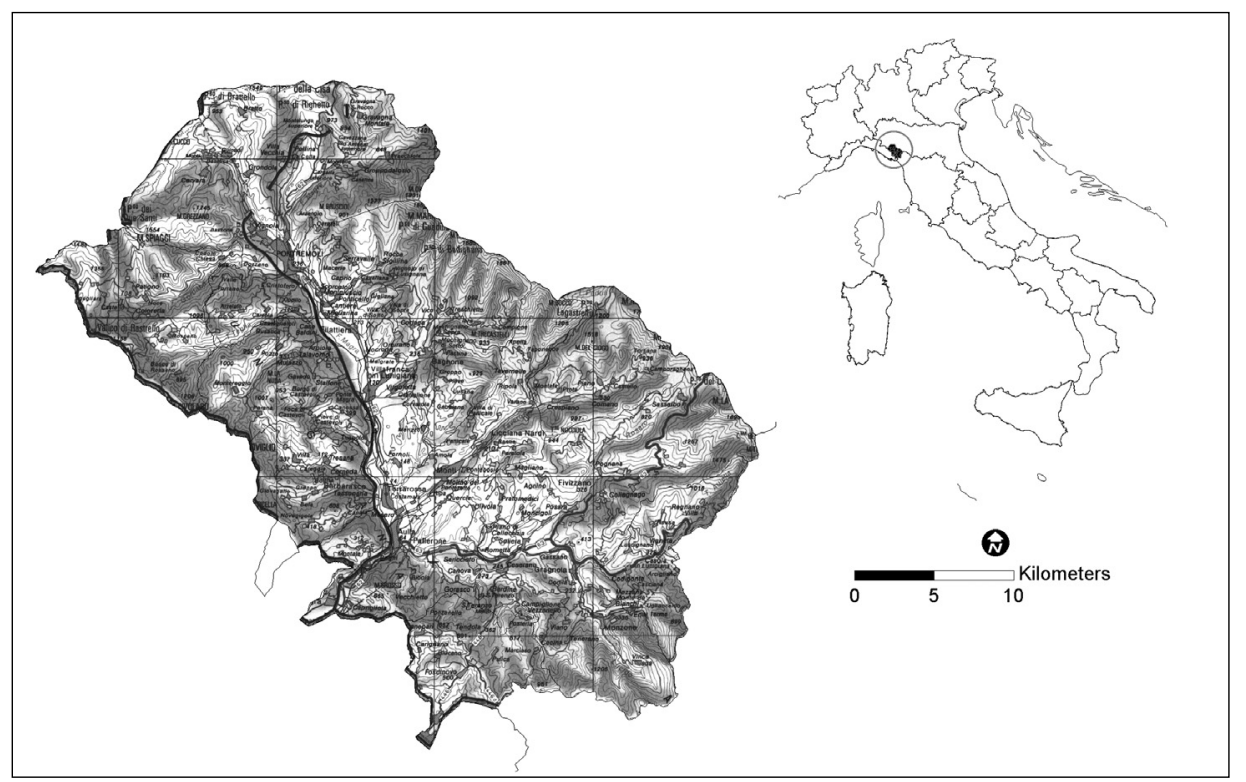

Figure 1. Location of the study area.

regional average, Lunigiana has higher density of agricultural machines per hectare of UAA (0.62 vs 0.21 ), a higher percentage of farms equipped with machines ( $71 \%$ vs $66 \%)$, and a higher irrigable surface ( $10 \%$ vs $8 \%)$. The farmland is mainly characterized by permanent crops, grasslands and woods particularly significant compared to the regional average (Tab. 1).

There is a widespread small-scale breeding concerning $47 \%$ of the farms which is more important than in the other mountains communities of the region (Tab. 2).

From a landscape point of view, Lunigiana maintains a substantially traditional texture and conserves interesting natural elements as proved by the presence of a complex and a heterogeneous system of protected areas.

\section{Materials and methods}

The research was developed with an integrated approach in two steps. This involved an up-scaling from a preliminary landscape analysis at a farm scale in terms of land use, farming systems and characterization of local farm contexts that

Table 1. Usable Agricultural Area and Total Agricultural Area in Lunigiana.

\begin{tabular}{|c|c|c|c|c|c|c|c|c|c|}
\hline \multirow{2}{*}{$\begin{array}{l}\text { Mountain } \\
\text { Communities }\end{array}$} & \multicolumn{4}{|c|}{ Usable Agricultural Area } & \multirow[b]{2}{*}{\begin{tabular}{|c} 
Wood \\
trees \\
plantations
\end{tabular}} & \multirow[b]{2}{*}{ Woods } & \multirow[b]{2}{*}{$\begin{array}{c}\text { Non } \\
\text { utilized } \\
\text { farmland }\end{array}$} & \multirow[b]{2}{*}{$\begin{array}{c}\text { Other } \\
\text { farmland }\end{array}$} & \multirow[b]{2}{*}{$\begin{array}{c}\text { Total } \\
\text { Agricultural }\end{array}$} \\
\hline & $\begin{array}{l}\text { Arable } \\
\text { Crops }\end{array}$ & $\begin{array}{l}\text { Permanent } \\
\text { crops }\end{array}$ & Grasslands & $\begin{array}{c}\text { Usable } \\
\text { Agricultural } \\
\text { Area }\end{array}$ & & & & & \\
\hline Lunigiana (ha) & 1,624 & 4,570 & 10,274 & 16,468 & 208 & 22,268 & 4,240 & 534 & 43,717 \\
\hline $\begin{array}{l}\text { on Total } \\
\text { Agricultural } \\
\text { Area }\end{array}$ & $3.7 \%$ & $10.5 \%$ & $23.5 \%$ & $37.7 \%$ & $0.5 \%$ & $50.9 \%$ & $9.7 \%$ & $1.2 \%$ & \\
\hline $\begin{array}{l}\text { Total of } \\
\text { Mountain } \\
\text { Communities } \\
\text { in Tuscany }\end{array}$ & 185,022 & 52,624 & 87,763 & 325,409 & 2,855 & 351,702 & 33,351 & 15,933 & 729,249 \\
\hline $\begin{array}{l}\text { on Total } \\
\text { Agricultural } \\
\text { Area }\end{array}$ & $25.4 \%$ & $7.2 \%$ & $12.0 \%$ & $44.6 \%$ & $0.4 \%$ & $48.2 \%$ & $4.6 \%$ & $2.2 \%$ & \\
\hline
\end{tabular}

Source: Istat - Agricultural census (2000). 
Table 2. Livestock farms in Lunigiana.

\begin{tabular}{|c|c|c|c|c|c|c|c|c|c|c|}
\hline \multirow{3}{*}{$\begin{array}{l}\text { Mountain } \\
\text { Communities }\end{array}$} & \multicolumn{10}{|c|}{ Livestock } \\
\hline & \multirow[b]{2}{*}{$\begin{array}{l}\% \text { livestock } \\
\text { farms }\end{array}$} & \multicolumn{3}{|c|}{ Cattle } & \multicolumn{3}{|c|}{ Sheep and goats } & \multicolumn{3}{|c|}{ Swine } \\
\hline & & $\begin{array}{c}\% \\
\text { farms }\end{array}$ & $\begin{array}{c}\text { Heads } \\
\text { density/ } \\
\mathrm{Km}^{2}\end{array}$ & $\begin{array}{l}\text { Average } \\
\text { farm } \\
\text { heads }\end{array}$ & $\begin{array}{c}\% \\
\text { farms }\end{array}$ & $\begin{array}{l}\text { Heads } \\
\text { density/ } \\
\mathrm{Km}^{2}\end{array}$ & $\begin{array}{c}\text { Average } \\
\text { farm } \\
\text { heads }\end{array}$ & $\begin{array}{c}\% \\
\text { farms }\end{array}$ & $\begin{array}{c}\text { Heads } \\
\text { density/ } \\
\mathrm{Km}^{2}\end{array}$ & $\begin{array}{c}\text { Average } \\
\text { farm } \\
\text { heads }\end{array}$ \\
\hline Lunigiana & 47.35 & 22.40 & 3.75 & 4.45 & 14.04 & 11.08 & 21.01 & 8.63 & 3.93 & 12.13 \\
\hline $\begin{array}{l}\text { Total Mountain } \\
\text { Communities } \\
\text { in Tuscany }\end{array}$ & 41.42 & 14.12 & 4.76 & 17.17 & 16.32 & 29.49 & 91.91 & 11.92 & 3.49 & 14.87 \\
\hline
\end{tabular}

Source: Istat - Agricultural census (2000).

led to the identification of six agro-landscape systems at a regional level, including their drivers of change or stability. Two areas (Northern and Southern areas) weren't included as agrilandscape systems because the farming activities resulted very scarce.

The first step was based on a sample of 56 farms $(60 \%$ of respondents in an initial sample) representative of local farming that mainly contributed to the maintenance of the traditional agricultural landscape in Lunigiana. In order to be representative of historical and aesthetic features and not just farming, the sample was chosen with the support of the Office for the Protection of Architectural, Natural, Historic, Artistic and Ethno-Anthropological Heritages, and of local Farmers' Unions.

At each farm we carried out a survey supported by an interview with the farmer based on a description:

1) of the location of the farm;

2) of the main farming practices producing landscape functions, pointing out the drivers of landscape conservation or landscape change;

3) of the typology and state of main agricultural land uses (in association with a description of how the farm was organized).

Based on the mainly mixed farming systems of the study area, six typologies were used: woods, agricultural permanent crops (including olive groves, vineyards, fruit orchards), grasslands (including their uses for forage, pasture or both), arable crops and specialized land uses, which were not related to mixed farming.

The location of the farm was also characterized using a GIS analysis (Software Arcview ArcGIS version 8.3, ESRI) consisting of two buffers of 150 meters (7.06 ha, corresponding to the area potentially coinciding to an important part of the farmland) and 400 meters (50.23 ha, corresponding to the area representative of the landscape context of the farmland) from the farm centre, already georeferenced through the survey. The buffers obtained were intersected with a Digital Elevation Model, slope and exposure, processed from the Regional Technical Cartography on the Region of Tuscany (1:10,000, 2001 edition). We then classed these results as criteria potentially influencing farm management and the farming system (Tab. 3).

Each geo-referenced point was linked to a farm card integrated with a photographical file. The information collected enabled us to obtain a preliminary description of the landscape and the identification of drivers in terms of stability and change at a regional level. The second step integrated the first results of the analysis with the expert knowledge in agricultural planning of technicians from the two local authorities (Comunità Montana and Province of Massa Carrara) and the three representative farmers unions for the area (Confederazione Italiana Agricoltori, Coldiretti, Unione Provinciale Agricoltori).

By applying participatory mapping methods based on local knowledge (Benoit et al., 2006), we asked the technicians to draw the main agricultural systems contributing to the landscape in Lunigiana directly onto a base map. The base map was obtained from the Tuscany Region map with a $1: 250,000$ scale, showing the principal morphological and topographical characteristics (e.g. rivers, roads, towns) in order to make it as easy and quick to understand for the stakeholders. Even though the case study area is quite large, we verified that the map scale permitted to the stakeholders to identify with a good level of detail the different ways of inter- 
Table 3. Main morphological parameters in the study area.

\begin{tabular}{ll}
\hline Morphological parameters & Classification criteria \\
\hline Aspect & We identified 6 classes considering the tendency of $1{ }^{\circ} \mathrm{C}$ decrease for each $100 \mathrm{~m}$ : \\
& $-100-200 \mathrm{~m}$ \\
& $-200-300 \mathrm{~m}$ \\
& $-300-400 \mathrm{~m}$ \\
& $-400-500 \mathrm{~m}$ \\
& $->500 \mathrm{~m}$ \\
& It is a conditioning factor to choose the land use in mountainous areas. We identified \\
& 4 classes: \\
& - NW-NE - worse \\
& - NE-SE and SW-NW - intermediate \\
& - SE-SW - best \\
& Based on these classes we identified the favourable exposure index which corresponds \\
& the buffer quota exposed from SE to NW. \\
& It is considered as the mechanization attitude. We identified 4 classes: \\
& $-0-5 \%$ - no problem for mechanization \\
& $-5-12.5 \%$ agricultural fields need some precautions to contain erosion and promote \\
& infiltration \\
& $-12.5-25 \%$ fields need hydraulic specific managements \\
& $->25 \%$ fields are not mechanizable. \\
Based on these classes we identified the favourable mechanization index which cor- \\
responds the buffer quota with slope percentage lower than $12.5 \%$ \\
\hline Slope
\end{tabular}

action between landscape and agricultural systems. We then asked for the main drivers of these systems that possibly contributed to the stability or change of the landscape. The systems identified and the associated trends were processed as geographical layers to allow for a final overlay and to elaborate a final representation at a regional level in terms of agri-landscape systems (Fig. 2).
The resulting map highlighted the similarities between the different information obtained from the stakeholders.

\section{Results}

The results highlight the landscape characterisation obtained at a farm level and subsequently integrated into the characterisation obtained at

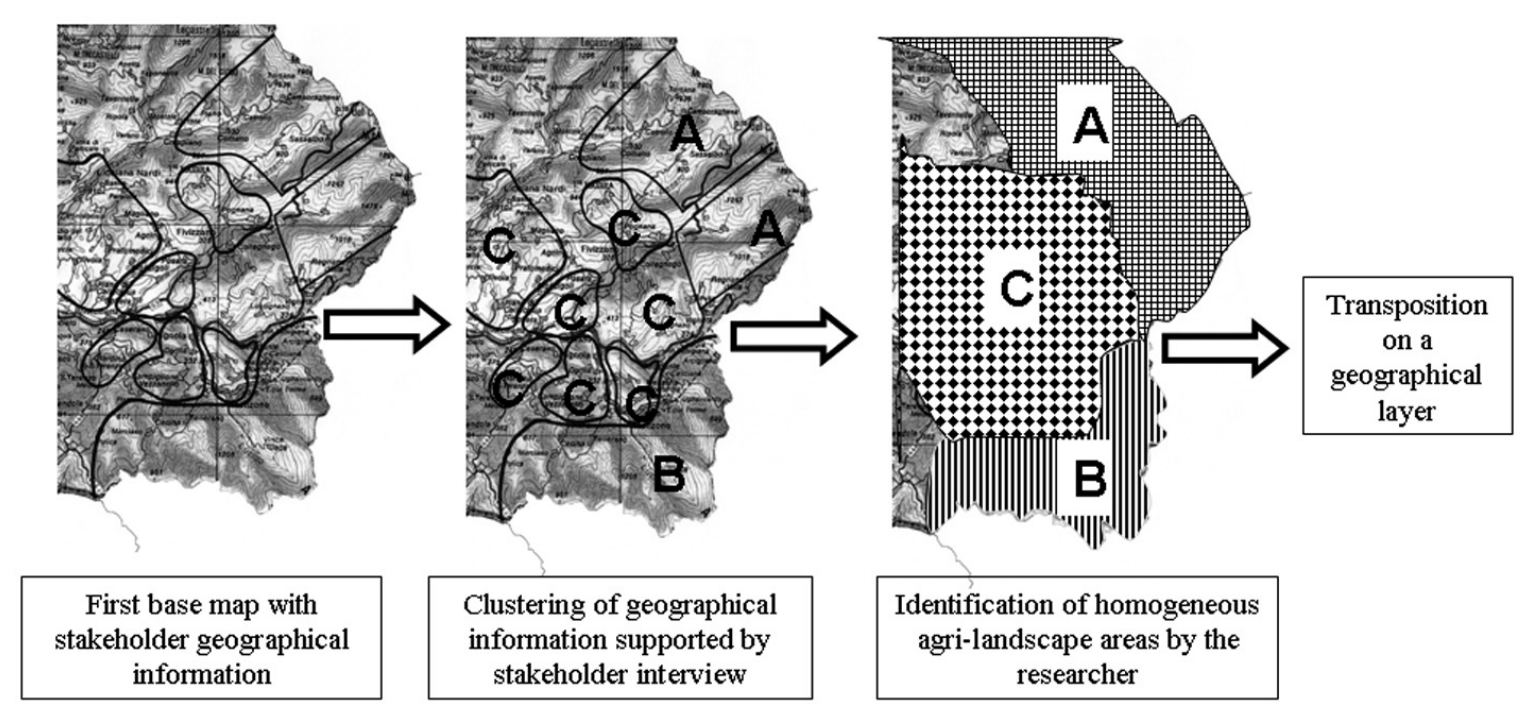

Figure 2. Transposition from base map to geographical layer. 
Table 4. Main combinations of the agricultural land uses in the on-farm sample.

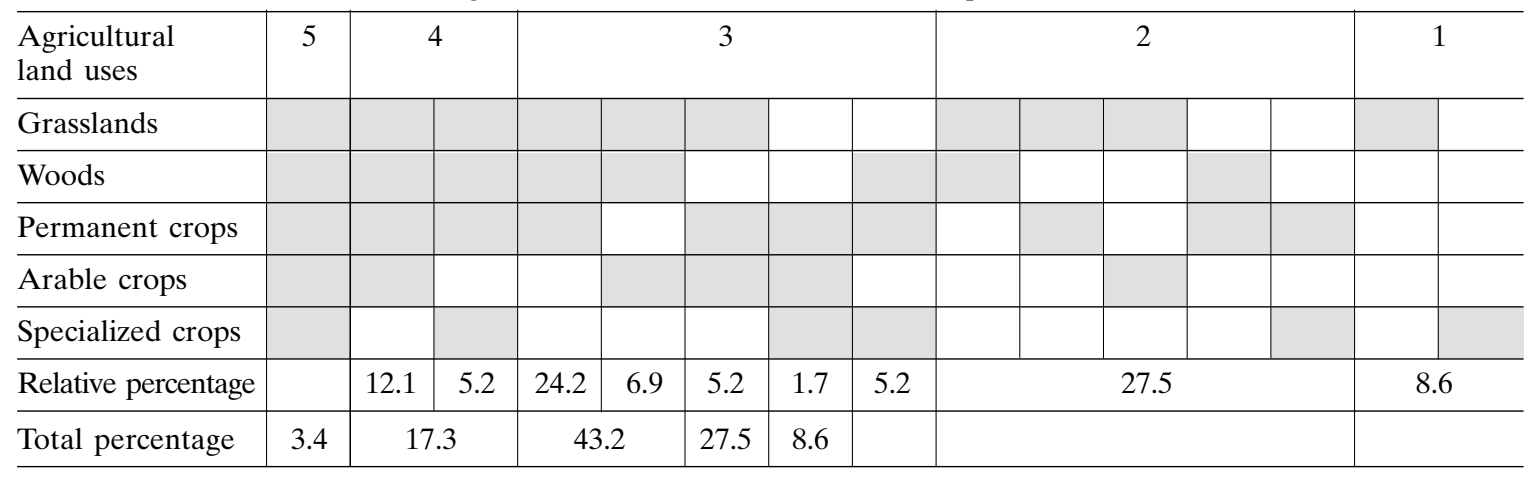

Elaborated from Galli et al., 2006.

a regional level. The main on-farm agricultural land uses showed (the percentages refer to the number of farms that presents the specific land use indicated):

- grasslands in $86 \%$ of the sample: used as meadows in $78 \%$, pastures in $57 \%$ and meadows-pastures in $26 \%$;

- woods in $70 \%$ of the sample: used for timber production in $53 \%$ and for chestnut production in $50 \%$;

- permanent crops in $70 \%$ of the sample. Of these, $68 \%$ was vineyards, $51 \%$ was olive groves and $42 \%$ was other fruit trees;

- arable crops in $20 \%$ of the sample, sometimes consisting of maize/wheat/alfa-alfa or maize/grass rotations;

- specialized crops in $22 \%$ of the sample. Of these, $54 \%$ was specialized in olive groves, $32 \%$ in vineyards, $15 \%$ in other trees.

An analysis of the combinations among the different agricultural land uses in each farm (Tab. 4) showed that in $17.3 \%$ of the surveyed farms there was a combination of four uses, whereas $43.2 \%$ of the farms there was a combination of three uses consisting in $24.2 \%$ of the farms of grasslands, woods and permanent crops. Finally in $27.5 \%$ of the farms, there was a combination of two agricultural land uses. Of these, $12.1 \%$ was grasslands with woods and $8.6 \%$ were grassland with permanent crops. Only in $8.6 \%$ of the farms there is only one use; of these $6.9 \%$ were grasslands. The farm data enabled us to identify several potential drivers influencing the agri-landscapes (Fig. 3).

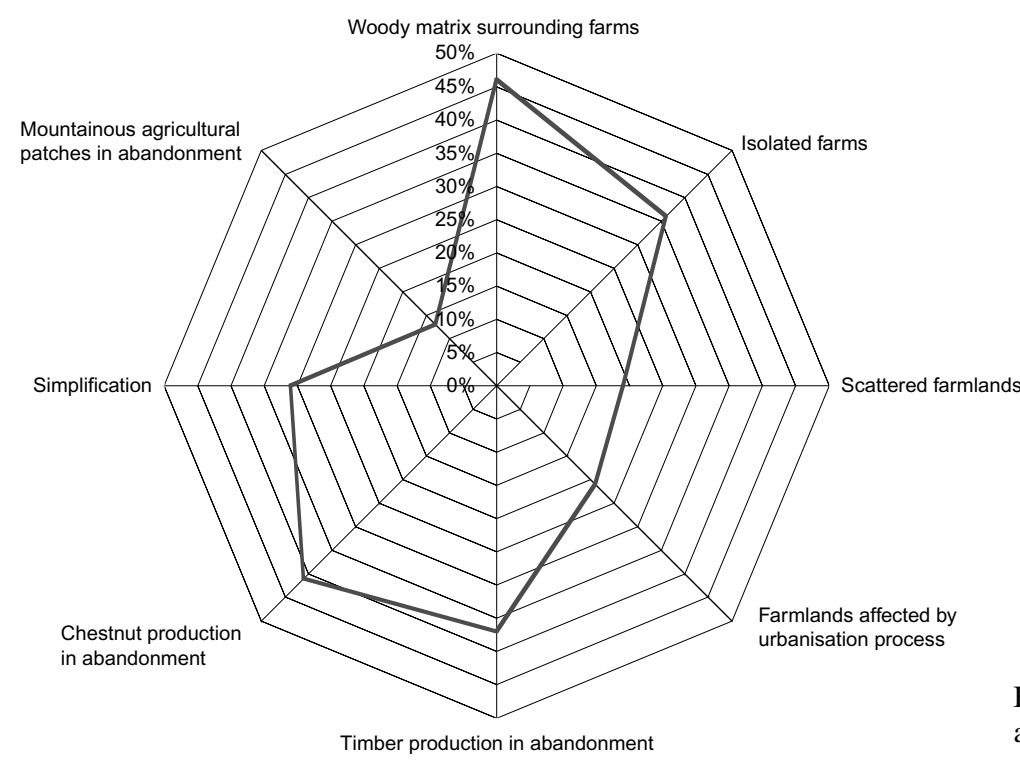

Figure 3. Main drivers influencing the agri-landscape. 
These were classified into two types: regional drivers, such as the landscape context including the farm, the isolation of the farm, the scattered farmland; and farm drivers such as simplification, specialisation or abandonment.

In terms of the farms drivers, in $46 \%$ of the cases, the farmland represented the only agricultural patch in a woody matrix. Moreover $36 \%$ of the farms was isolated. These are two competing drivers for re-naturalisation and loss of openness of the landscape. This is due, on the one hand, to the proximity to gene-flow sources from woods, and on the other hand a lack of potential compensation effects from other farms in maintaining the agricultural patches. Nineteen per cent of the farms presented a scattered farmland, which in mountainous areas depends on the availability of different seasonal pastures, and in the hilly ones on potential fields for arable crops. When there were not many fields or when they were far from the farm centre they were more frequently abandoned. On the plains, land use was affected by urbanization processes ( $21 \%$ of the surveyed farms).

With regards to the main farm drivers, we found some contrasting cases. In terms of the woods, timber production had been abandoned in $37 \%$ of cases, whereas their use was limited in $48 \%$ (purely to satisfy household needs); regarding chestnut production, $41 \%$ had been abandoned and $14 \%$ was limited to the harvesting of chestnuts. Some farmers intended to re-start chestnut production but on limited to small surfaces (1.5-2 hectares).

There was an extensification process in charge of grasslands. Farmers were using them only for one cut per year, leaving them for the rest of the time as pastures or converting them into pastures in order to reduce production costs. Extensification or abandonment also affected arable crops ( $31 \%$ of the sample). This was also evident in flat areas near rivers, with potential effects on the diversity of the landscape.

Permanent crops were subject to specialisation, even though some traditional patches still remained.

In the mountainous areas, the agricultural patches nearby the villages were also characterised by abandonment $(13 \%$ of the farms surveyed).

Lastly, $90 \%$ of the sample with agri-tourist

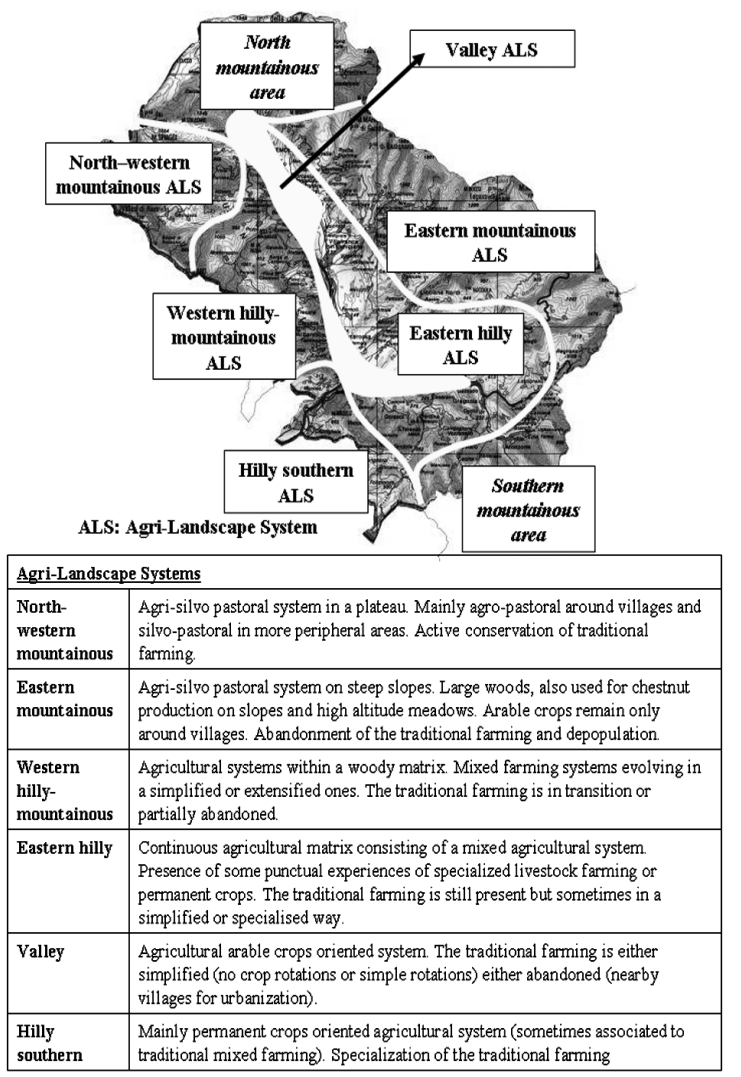

Figure 4. Agri-landscape systems.

services presented a low mechanisation index in their first buffer $(150 \mathrm{~m})$. This suggested a compensation strategy for farms that are in marginal areas for crop production. This is not the case for the farms with a stable (where the low mechanization index affected $65 \%$ of the cases) or other buildings for processing agricultural productions (62\%).

The integration of these preliminary results in terms of the characterisation of the landscape at a regional level, supported by the expert knowledge of local technicians, enabled us to identify six agri-landscape systems (Fig. 4):

- North-western mountainous system: this corresponds spatially to the municipality of Zeri. It is characterised by a significant livestock activity combined with wood production, especially chestnuts. It is a silvo-pastoral system mainly dominated by sheep, characterised by agricultural activities in proximity to the villages. This system differs from other mountainous ones because of the strong rural community that has maintained and re- 
newed its local resources (e.g. Consortium for the conservation of Zerasca sheep). Traditional agricultural systems of family farming still remain, apart from the limited experiences of specialisation in cattle activities. Except for the more distant pastures, the landscape has been preserved. This is mainly due to (a) the geographical characteristics of the area, which is a high altitude plateau, (b) the settlement structure, which is composed of a series of neighbouring villages and (c) the active management of common pastures. From a landscape point of view the system is characterised by a mosaic of open patches (grasslands for forage and pastures) mixed with woods and a few permanent and arable crops in proximity to the villages.

- Eastern mountainous system: this is a silvopastoral system which once had a strong agricultural identity. This was due to a significant chestnut production, the presence of pasture paths to move livestock from the hilly areas to the neighbouring mountainous pastures in the summer and to several villages along such paths. However, over the last few decades, these systems have been abandoned, resulting in a strong decrease in high altitude pastures, chestnut woods and mountainous arable crops such as winter wheat and other cereals (barley, spelt), and potatoes. Some limited areas in the northern and southern parts have residual and renewed livestock and chestnuts productions. From a landscape point of view the system is characterized by two landscapes depending on morphology. We can identify two belts: the first is characterized by major altitudes and the prevalence of mountain pastures. The second is characterized by a wood matrix with several agricultural patches in proximity to small villages.

- Western hilly mountainous system: this is mainly characterized by the traditional dominance of woods because of its scarce agricultural suitability due to the steep slopes. In this woody matrix there were several isolated agricultural patches around isolated farms and villages. Over the last few decades, these patches have been simplified (arable crops had disappeared) or specialized (with presence of vineyards or olive groves). It is a system in transition, abandoning traditional agricultural systems and developing new farming strategies. From a landscape point of view the system is characterised by a continuous woody matrix with agricultural patches where different land uses prevail (mixed farming and more specialised farming).

- Eastern hilly system: this was identified as a mixed farming system, making up most of the Lunigiana agricultural landscape. It is a large system with a continuous matrix that can be divided into three sub-systems. The first is located in the north between the municipalities of Pontremoli and Licciana Nardi. It has a small-scale livestock activity, and contributes to the openness of the landscape through the conservation of pastures and meadows. The second is located in the north of the municipality of Fivizzano and is characterized by the prevalence of olive groves, in small areas of vineyards, also in a specialized production. Lastly, the southern part of the municipality of Fivizzano (including part of the municipality of Casola di L.) is characterized by a larger diffusion of mixed permanent crops (vineyards, olive and fruit groves, the latter being more widespread than in other systems).

This system is classified as stable, though over the last few decades, it has been simplified with the disappearance of the traditional agropastoral system. From a landscape point of view it is characterised by continuous agricultural patches, which represent a traditional mixed family farming.

- Valley system: this is a system mainly devoted to arable crops (cereals and forages) because of the plain morphology, the presence of an alluvial platform and the possibility of irrigation. However, because of the depth of the soil, not all the plain is tilled, so agricultural patches are fragmented by natural areas that are protected by specific measures. The main crop rotation is maize/winter wheat ( 1 or 2 years) meadow or alfa-alfa (2 or 3 years). This system is characterized by an abandonment of agricultural activities, still being managed by residual small family farms and by rent and bailment agreements. This is leading to a simplification of crop rotations, often resulting exclusively in meadows. From a landscape point of view the system is charac- 
terised by a continuous agricultural matrix, alternating with natural areas.

- Hilly southern system: this is dominated by permanent crops, resulting in viticulture on the plains, or olive groves on the slopes. Because of its location near to the coastal plain (an important agricultural area) and its favourable agronomical conditions, the farming systems are more oriented to the market. From a landscape point of view the system is characterised by the definition of new combinations of land uses although the land use is traditional (with the prevalence of permanent crops).

The northern and southern mountainous systems are scarce in agricultural activities, because of the prevalence of woody or natural matrixes. Consequently, local experts were not able to define the possible drivers of these farming systems.

These six systems of agri-landscapes in Lunigiana could provide an initial basis for discussing the possible measures needed to preserve and manage the agriculture and landscape in an integrated way.

\section{Discussion}

Our analysis highlighted three main methodological issues for agronomical research applied to landscape studies.

Firstly, the case study pointed out the relevance of multi-scale approaches and the inclusion of the regional level in agronomy research. We believe there is a need to adopt new research methods and tools in order to respond to different situations in terms of data availability, such as qualitative data when quantitative data are scarce or not suited to the objective of the research. This also applies to the analysis of the landscape drivers in complex systems.

Secondly, it was useful to include the landscape within agro-environmental studies and to consider it as a component of the production of agricultural goods and services at a farm and regional scale.

Thirdly, the results showed the need for discussions among researchers, farmers and local decision-makers concerning agricultural landscape management and conservation strategies.
Concerning this last point, during the interviews with the experts we received specific proposals related to the identified systems, which may contribute to support decision-makers.

Finally, possible improvements in our methodology include a significant statistical sample and a possible land use analysis of the neighbouring farms through aerial photos in order to quantify the main agricultural land uses.

\section{Acknowledgment}

We acknowledge the English review of the manuscript by Adrian Wallwork and technicians from the two local authorities (Comunità Montana and Province of Massa Carrara) and the three representative farmers unions in the area (Confederazione Italiana Agricoltori, Coldiretti, Unione Provinciale Agricoltori). In addition we acknowledge Dr Davide Rizzo and Dr Stefano Bacci for their contribution during the initial farm level research.

\section{References}

Antrop M., Rogge E. 2006. Evaluation of the process of integration in a transdisciplinary landscape study in the Pajottenland (Flanders, Belgium). Landscape Urban Plan, 77:382-392.

Benoit M., Deffontaines J.P., Lardon S. 2006. Acteurs et territoires locaux. Vers une géoagronomie de l'aménagement. SavoirFaire, Paris.

Bonari E., Galli M., Rizzo D. 2006. Gestione del territorio rurale e paesaggio. In: Lorenzi R., Semprini M.P. (eds.): La tutela del paesaggio tra economia e storia, 47-56. Ed. Ministero per i Beni e le attività culturali, Associazione Arspat.

Borin M., Ceccon P. 2002. I sistemi colturali nella ricerca agronomica: un problema di scala. In: Bonari E., Ceccon P. (eds.): Verso un approccio integrato allo studio dei sistemi colturali, 11-45. Franco Angeli, Milano.

Capitaine M., Benoît M. 2001. Territoires des exploitations et finages: mutations lorraines. Mappemonde, 62:6-9.

Carpani M., Giupponi C., Trevisiol P. 2008. Evaluation of agro-environmental measures in the Venice Lagoon watershed. Nitrogen budgets and surplus indicators. Italian Journal of Agronomy, 3:167-182.

Deffontaines J.P., Thenail C., Baudry J. 1995. Agricultural systems and landscape patterns: how can we build a relationship? Landscape Urban Plan., 31:3-10.

Doré T., Clermont-Dauphine C., Crozat Y., David C., Jeuffroy M.H., Loyce C., Makowski D., Malézieux E., Meynard J.M., Valantin-Morison M. 2008. Methodological progress in on-farm regional agronomic diagnosis. A review. Agron. Sustain. Dev., 28:151-161. 
Galli M., Balducci E., Debolini M., Marraccini E., Rizzo D., Bonari E. 2008. Defining scenarios for local agricultural systems development through participatory approach: a case study in the Grosseto Province (Tuscany, Italy). In: Dedieu B., Zasser-Bedoya S. (eds.): Proceedings of the 8th IFSA Symposium, 6-8 July 2008, Clermont-Ferrand, France, 2.

Galli M., Rizzo D., Bonari E. 2006. Le funzionalità paesaggistiche dell'attività agricola: il caso di studio della Lunigiana. Agribusiness Landscape \& Environmental Management, IX, 1:67-74.

Giupponi C., Carpani M. 2006. Recent developments in indicators and models for agri-environmental assessment. Italian Journal of Agronomy, 1:647-664.

Giupponi C., Fassio A., Sgobbi A. 2008. Evaluation of agro-environmental measures in the Venice Lagoon watershed. Expert knowledge elicitation and multi-criteria analysis. Italian Journal of Agronomy, 3:147-166.

ISTAT (2000). Censimento generale dell'agricoltura.

Lardon S., Piveauteau V. 2002. Chorèmes and territorial diagnosis: a training experiment. Mappemonde, 68:1-6.

Lichtfouse E., Navarrete M., Debaeke P., Souchère V., Alberola C., Ménassieu J. 2009. Agronomy for sustainable development. A review. Agron. Sustain. Dev., 29:1-6.

Marraccini E., Rapey H., Galli M., Lardon S., Bonari E. 2008. A method to appraise multiple agro-environmental functions in farming regions. Italian Journal of Agronomy, 3:303-304.

Paquette S., Domon G. 2003. Changing ruralities, changing landscapes: exploring social recomposition using a multi-scale approach. J. Rural Stud., 19:425-444.

Primdahl J. 1999. Agricultural landscapes as places of production and for living in owner's versus producer's decision making and the implications for planning. Landscape Urban Plan., 46:143-150.

Ragaglini G., Villani R., Guidi W., Bonari E. 2008. Bioenergy production assessment at regional level under different scenarios of resources exploitation. Aspects of Applied Biology, 90:109-118.
Roggero P.P., Silvestri N. 2002. Elementi per un'analisi integrata dei sistemi colturali. In: Bonari E., Ceccon P. (eds.): Verso un approccio integrato allo studio dei sistemi colturali, 121-144. Franco Angeli, Milano.

Roggero P.P., Seddaiu G., Toderi M. 2006. Stakeholder analysis for sharing agro-environment issues towards concerted actions: a case study on diffuse nitrate pollution. Italian Journal of Agronomy, 1:727-740.

Thenail C., Baudry J. 2004. Variation of farm spatial land use pattern according to the structure of the hedgerow network (bocage) landscape: a case study in northeast Brittany. Agr. Ecosyst. Environ., 101:53-72.

Thenail C., Joannon A., Capitaine M., Souchère V., Mignolet C., Schermann N., Di Pietro F., Pons Y., Gaucherel C., Viaud V., Baudry J. 2009. The contribution of crop-rotation organization in farms to cropmosaic patterning at local landscape scales. Agr. Ecosyst. Environ., 131:207-219.

Van Ittersum K., Ewert F., Giller K. 2007. Integrated assessment of farming systems. In: Donatelli M., Hatfield J., Rizzoli A. (eds.): Proceedings of "Farming System design 2007: an international symposium on Methodologies for Integrated Analysis of Farm production Systems", September 10-12, Catania, Italy.

Van Mansvelt J.D. 1997. An interdisciplinary approach to integrate a range of agro-landscape values as proposed by representatives of various disciplines. Agr. Ecosyst. Environ., 63:233-250.

Veldkamp A., Kok K., De Koning G.H.J., Schoorl J.M., Sonneveld M.P.W., Verburg P.H. 2001. Multi-scale system approaches in agronomic research at the landscape level. Soil Till. Res., 58:129-140.

Verburg P.H., Schulp C.J.E., Witte N., Veldkamp A. 2006. Downscaling of land use change scenarios to assess the dynamics of European landscapes. Agr. Ecosyst. Environ., 114:39-56.

Viglizzo E.F., Pordomingo A.J., Castro M.G., Lértora F.A., Bernardos J.N. 2004. Scale-dependent controls on ecological functions in agroecosystems of Argentina. Agr. Ecosyst. Environ., 101:39-51. 